\title{
A CASE OF OSTEOMALACIA IN HUMAN SKELETAL REMAINS FROM ST HRIPSIME CHURCH (HOROM, ARMENIA)
}

\author{
A.Yu. Khudaverdyan ${ }^{1}$, A.A. Yengibaryan ${ }^{2}$, \\ A.A. Hovhanesyan ${ }^{3}$, H.H. KhaChatryan ${ }^{4}$, L.G. Yeganyan ${ }^{4}$ \\ ${ }^{1}$ Institute of Archaeology and Ethnography, National Academy of Sciences, Yerevan, \\ Republic of Armenia \\ ${ }^{2}$ Yerevan Mkhitar Heratsi State Medical University, Yerevan, Republic of Armenia \\ ${ }^{3}$ Armenian Republican Medical Centre, Yerevan, Republic of Armenia \\ ${ }^{4}$ Shirak Centre of Armenian Studies, National Academy of Sciences, Republic of \\ Armenia
}

\begin{abstract}
In this study, we investigated the remains of an individual that were recovered during cleansing work of the Church of St Hripsime. Macroscopic and X-Ray inspections yielded pathological criteria which indicated osteomalacic origin. The findings of the study suggest that the individual who lived in the Late Medieval period may have gone through multiple episodes of vitamin D deficiency. Vitamin D deficiency as an effect of deficient exposure to sunlight (in particular, in rural individuals who lived in underground houses) and nourishment deficiency could be described as the main causes leading to osteomalacia in Armenia.
\end{abstract}

Keywords: Osteomalacia; pseudofracture; curvature of the sterna and sacrum; $X$-ray; the Middle Ages; Armenia

\section{INTRODUCTION}

Osteomalacia is a disorder which affects the skeleton; the most frequent cause of osteomalacia is nutritional vitamin D deficiency, and it occurs almost exclusively in the parts of the world where vitamin D insufficiency is endemic [9, 6]. It is characterized by mineralization insufficiency of the osteoid matrix in 
the cortical and trabecular bone, resulting in amassing of osteoid tissue [18]. Factors that increase the exposure of the skin to sunlight and also the addition of dietary sources of vitamin D can contribute to the absence of skeletal manifestations of absence [26, 12]. It would be expected that vitamin D levels would be higher closer to the equator where sunlight is intense. However, other studies have shown the contrary, with levels higher in northern than in southern Europe [45, 62]. This may partly be explained by skin pigmentation $[29,30,54,55]$. People in warmer climates tend to have darker skin pigmentation, which may affect their capacity to synthesise vitamin $\mathrm{D}$. White women in South England had median 25(OH)D levels of $62.5 \mathrm{nmol} / \mathrm{l}$ in summer and $39.9 \mathrm{nmol} / \mathrm{l}$ in winter, while in Asian women living in the same geographical region the median levels were considerably lower at $24.9 \mathrm{nmol} / \mathrm{l}$ and $16.9 \mathrm{nmol} / \mathrm{l}$ respectively [38]. Type of clothing is another determinant of the amount of UVB radiation that will reach the skin [15]. Vitamin D can be ingested as ergocalciferol (vitamin D2) or cholecalciferol (vitamin D3). Ergocalciferol is received from plant sources such as mushrooms, whereas cholecalciferol is contained mainly in egg yolk and oily fish. Sustenance of adequate levels of vitamin D has a significant effect on the immune function [63] and development of neoplastic diseases [31]. Another form of osteomalacia may result from inherited and acquired conditions [26]. Vitamin D deficiency is a pathogenic factor of osteoporosis that may be modified [56, 5]. Some reviews have shown considerable differences in vitamin D levels related to age [45, $25,4]$.

In the Middle East and Africa, children trend to have higher vitamin D levels than adults [23]. This can reflect the greater amount of time they spend outside compared to other age groups. However, it has been shown that these distinctions are decreasing, which may be the result of a change in lifestyle in developed regions, with younger people spending a greater amount of time indoors [24]. The extreme old-age population has been found to be a group at special risk of vitamin D deficiency.

Pseudofractures involving part of the cortex (or extending completely across bones) are the most typical X-ray signs of osteomalacia and are virtually diagnostic [58]. The classical description of this peculiarity was given by Looser [36]. Typically, pseudofractures are some millimetres in thickness and quite sharply defined from the contiguous mineralized bone. Stresses exerted on such defectively mineralized bone result in little, linear fractures $[49,39]$. Clinical literature suggests two causative mechanisms for these defects; one concerning the pressure or pulsations of arteries on weakened bone tissue $[35,61,39]$, and the second invoking a fracture response in weakened bone 
to muscle and soft tissue forces during normal motion $[39,1,22,8]$. The deficiency of the mineral matrix in osteomalacia can explain the localization of many of Looser's zones. The concept that they start as easy fractures in bones which are pathologically weakened is acceptable, and their symmetry may be explained by the fact that many of the habitual stresses such as walking or breathing are likely to affect both sides of the body similarly. Pseudofractures may ultimately result in a full fracture [35]. In paleopathology, this type of fracture is a key means for suggesting the diagnosis of osteomalacia [12, 28]. With convalescence, ossification of the fracture callus will occur. This can be irregular if surplus osteoid has accumulated at the fracture sites. These factors score for the presence of speculated or amorphous new bone formation surrounding lesion margins [14].

Our interest in osteomalacia was aroused by recognising the disease in the individual discovered in the ruins of the ancient St Hripsime Church (Horom village in the Shirak Province of Armenia). Bioarchaeologically, few cases of osteomalacia have been identified, and very little work has been undertaken on documenting the scope of osteological features characteristic of the condition. Unquestionably, the full range of skeletal expressions is still not known. Studies by Mensforth [43], Brickley et al. [14] and Ives and Brickley [28] have highlighted cases of osteomalacia occurring in urban populations affected by industrial living and increased atmospheric pollution.

The aim of this study was to investigate the living conditions of the individual from Horom through an examination of the full range of pathological changes linked to osteomalacia. Specifically, we tested the hypothesis that vitamin $\mathrm{D}$ deficiency was linked to a range of social and economic factors that affected the village inhabitant in the Shirak Province of Armenia.

\section{MATERIAL AND METHODS}

The skeleton was recovered from a church (burial) during excavations undertaken by the Armenian archaeologists $\mathrm{H}$. Khachatryan and L. Yeganyan at the village of Horom in 2018 (Figure 1). It is presently curated by the Laboratory of Physical Anthropology at the Institute of Archaeology and Ethnography, NAS RA in Yerevan. The individual was interred in a supine position and belonged to the Late Middle Ages. The body of the individual was deposited in the southeast direction. Most of the skeleton was preserved, except for the pubic region of the pelvis, right femur, tibias, fibula and foot bones. The bone inventory of the analysed skeleton can be seen in Figure 1. The sex and of the individual the age at the death were defined according to standard osteological methods 

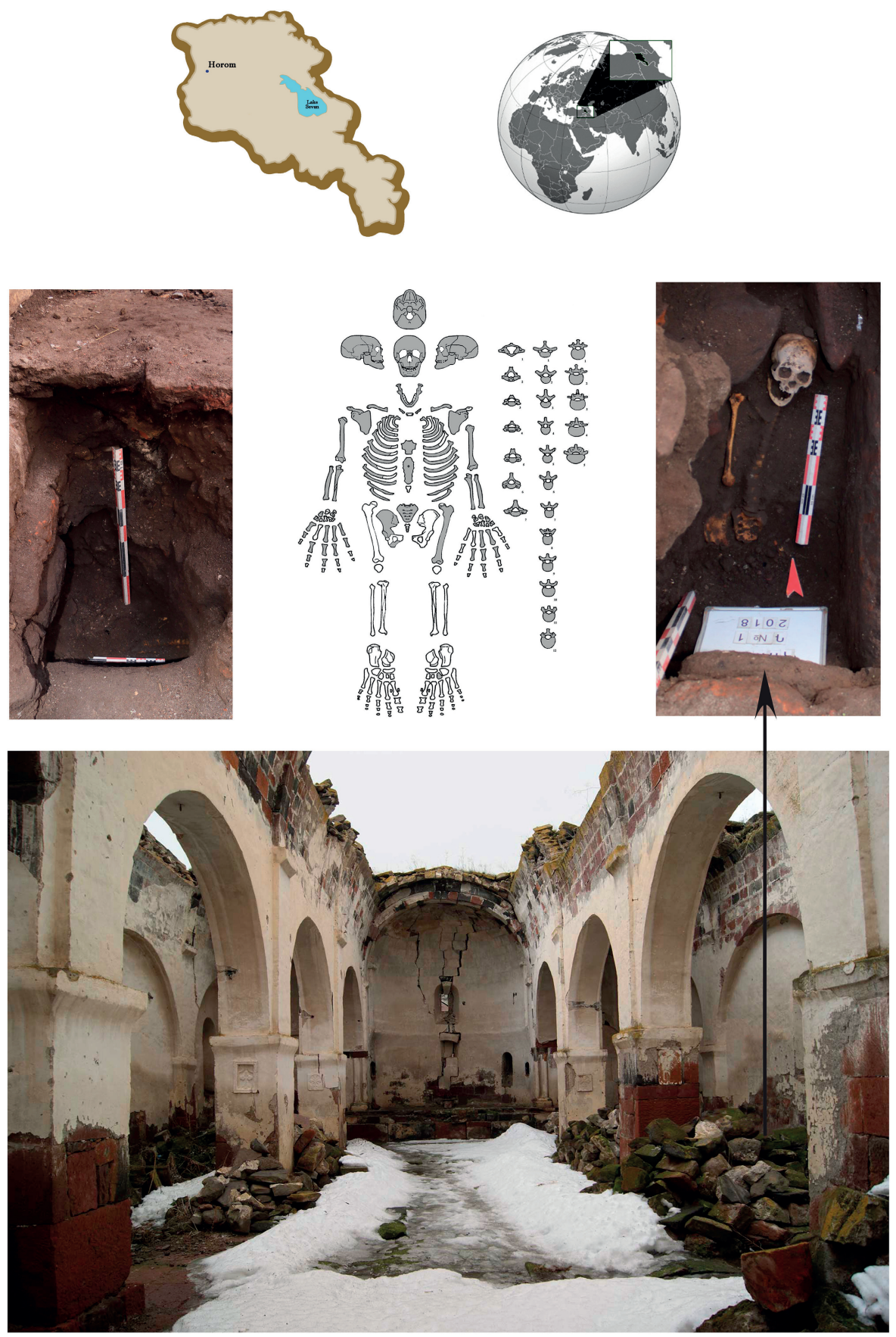

Figure 1. St Hripsime Church, plan of Burial 1 (in situ, with a curved spine), available skeletal elements from Burial 1 in St Hripsime Church 
$[7,16,17,37,42,60]$. Sex estimation was based on observation of the shape and depth of the greater sciatic notch and cranial dimorphic characteristics [17]. The age at the death was estimated, based primarily on the morphological features of the right auricular surface [57], cranial sutures, and dental wear of the molars.

Stature reconstruction was based on the length of the long bones of the limbs by the formulae of Pearson-Lee [2]. Careful macroscopic assessment of all skeletal elements was undertaken. Macroscopic analysis of a diversity of postcranial features was made following the criteria of bone changes in osteomalacia outlined in Brickley et al. [13], Ives and Brickley [15]. Lesions formed of well remodelled novel bone were considered as a healed state [53].

In the current study, X-rays were made from different sites in the skeleton that are predilected for fractures. Depending upon the bone element radiographed, exposures ranged from $65 \mathrm{kv} / 10 \mathrm{~s}$ for scapula, $54 \mathrm{kv} / 10 \mathrm{~s}$ for ribs to $87 \mathrm{kv} / 10 \mathrm{~s}$ for femora. Bones were radiographed at the Armenian Republican Medical Centre.

\section{RESULTS AND DISCUSSION}

The skeleton was a man's, he had been between 40 and 55 years old at death, his height was $161.2 \mathrm{~cm}$. The series of macroscopic and X-Ray evidence supporting the diagnosis of osteomalacia and social and cultural interpretations of the presence of the condition are discussed below. The pathological changes identified in this research are described below and are displayed in Table 1 and in Figures 2 and 3. 
Table 1. Distribution of the skeletal changes in adult osteomalacia

\begin{tabular}{|c|c|}
\hline Lesion & Individual 17 \\
\hline Scapula spinous process pseudofracture & No \\
\hline Scapula spinous process unilateral pseudofracture & No \\
\hline Scapula spinous process bilateral pseudofracture & No \\
\hline Scapula spinous process posterior pseudofracture & No \\
\hline Scapula spinous process anterior pseudofracture & No \\
\hline Single pseudofracture of scapula spinous process & No \\
\hline Multiple pseudofractures of scapula spinous process & No \\
\hline $\begin{array}{l}\text { Scapula spinous process pseudofracture visible with small callus at } \\
\text { margins, initial fracture healing }\end{array}$ & No \\
\hline Scapula spinous process bridging of pseudofracture with woven formation & No \\
\hline Scapula spinous process woven bone formation without a pseudofracture & Yes \\
\hline Scapula spinous process lamellar bone formation & No \\
\hline Scapula coracoid process pseudofracture & No \\
\hline Scapula lateral border pseudofracture & Yes \\
\hline Scapula lateral border curvature & Yes \\
\hline Healing or unhealed rib fractures & Yes \\
\hline Inferior pubic rami unhealed pseudofracture & - \\
\hline Pubic symphysis angulation & - \\
\hline Iliac crest fracture & No \\
\hline Ilium pseudofracture & Yes \\
\hline Sternum bending & Yes \\
\hline Vertebra body compression fracture & Yes \\
\hline Incomplete, linear vertebra cortical fractures & Yes \\
\hline Healing or unhealed clavicle fracture & No \\
\hline Distal ulna unhealed fracture. & No \\
\hline Proximal femur pseudofracture & No \\
\hline Linear raised pseudofracture proximal medial femur & No \\
\hline $\begin{array}{l}\text { Antero-lateral bending proximal femur without residual deformities of } \\
\text { rickets }\end{array}$ & No \\
\hline Antero-lateral bending proximal femur with residual deformities of rickets & No \\
\hline Platymeria & No \\
\hline
\end{tabular}




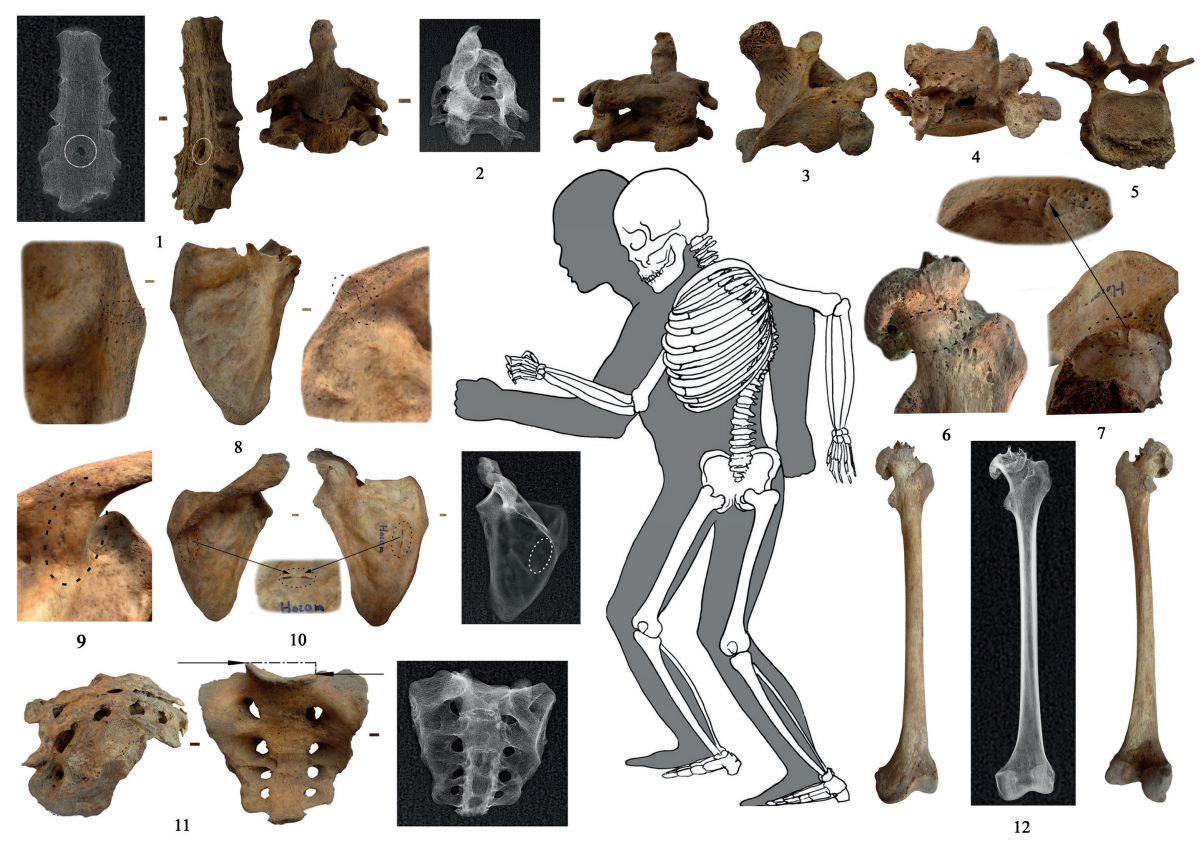

Figure 2. Curvature of the sternal, sternal foramen (1), cervical vertebrae 2-3 are fused into a single block (2), view from posterior of an irregular linear pseudofracture (arrows) at the transverse process of a thoracic vertebra (3), porous woven new bone over the transverse process of a lumbar vertebra (4), a crush fracture of the vertebral body (5), raised, linear ridges of bone formation along the inferior margin of the left femoral neck (6), a severe trochanteric fracture (7), pseudofracture of the scapula $(8,10)$, shallow, incomplete formation of porous woven new bone over the scapula spinous process without a fracture (9), curvature of the sacrum (11).

\section{Individual diagnosis}

Scapulae. The body of the right scapula had one elongated defect extending on the lateral and posterior edge of the middle third of the body top (Figure 2-10). The lower vertical fracture started from the lateral end of the transverse fracture and ended at the lower medial third of the body. The individual had a spread of porous woven bone formation over the scapula spinous process (Figure 2-9). This was similar to the deposit of woven bone that had formed over a thin fracture line. Fractures in this region are reported in osteomalacic individuals examined in pathological collections $[13,46]$. The left scapula showed a pseudofracture on the medial border of the left scapula (Figure 2-8). The feature occurred bilaterally, although variation existed as to the severity of the defect between the left and the right scapulae. Posterior curvature of the scapula (viewed from medial side) as a result of softened bone was also noticeable. 
Sternum. Lateral curvature of the sternum was observed. A round perforation was noted on the distal portion of the gladiolus of the sternum $(8.5 \times$ $5.5 \mathrm{~mm}$ ) (Figure 2-1). It was located at the level of articular facets of the fifth costal cartilages in the midline. However, it is possible that this is a sternal foramen where 2 sternebrae did not fuse completely during formation. Ives and Brickley [28] believe that the curvature in the scapula and sternum are connected to underlying osteomalacia.

Vertebrae. Spinal defects can happen in osteomalacia, whereby softening of the bone in the vertebral body will lead to weakening and a failure to withstand weight-bearing pressure and thus collapse [13].

At the time of excavation, the spine of the individual had an unusual curvature (Figure 1). Cervical vertebrae $2-3$ were malformed and fused into a single block (Figure 2-2). The vertebrae were fused through adjoining articular facets and bodies. The intervertebral disc space had disappeared, but small, not fused areas in the anterior part could be seen. The lateral direction roentgenogram revealed that the fusion of the posterior parts was complete, the radiolucent areas between the two vertebral plates suggested ankylosis. Such bone growth is unlikely to be accounted for by osteomalacia. However, where spinal defects are present with scapula fractures and rib fractures (see below), review should be given to an underlying vitamin $\mathrm{D}$ deficiency.

The inter-vertebral discs expanded and pressed against the adjacent bone, producing a concavity in the superior and inferior surfaces of the body because of the softened condition of the bone [51]. This type of vertebral deformity has been marked as "biconcave codfish appearance" $[22,13]$. Such defects can promote spinal curvature defects and can be seen in both osteomalacia and osteoporosis [13].

Three upper thoracic (T2-T4) and lumbar laminae (L3-L4) (Figures 2-3, 2-4) were affected by a series of small, incomplete, linear cortical fractures. These fractures were located adjacent to the inferior margins of the transverse process and were surrounded by porous friable new bone. These appeared like osteomalacic pseudofractures [28].

Ribs. This individual had a mixture of well-healed, and remodelling fractures (Figure 3). Multiple fractures (12 of 24 ribs) often occurred close together. Rib fractures can result from interpersonal violence, accidental trauma and pathological conditions $[10,33,40]$.

Sacra. Features of osteomalacia in this region included severe curvature (or angulation) predominantly occurring at the inferior margin of the third sacral segment [13]. The body of the sacrum was displaced anteriorly, which, 
appearing with anterior kyphosis of the lower lumbar vertebrae, contributed towards obstructing the pelvic canal. The angulation deformity was severe and noticeable (Figure 2-11).
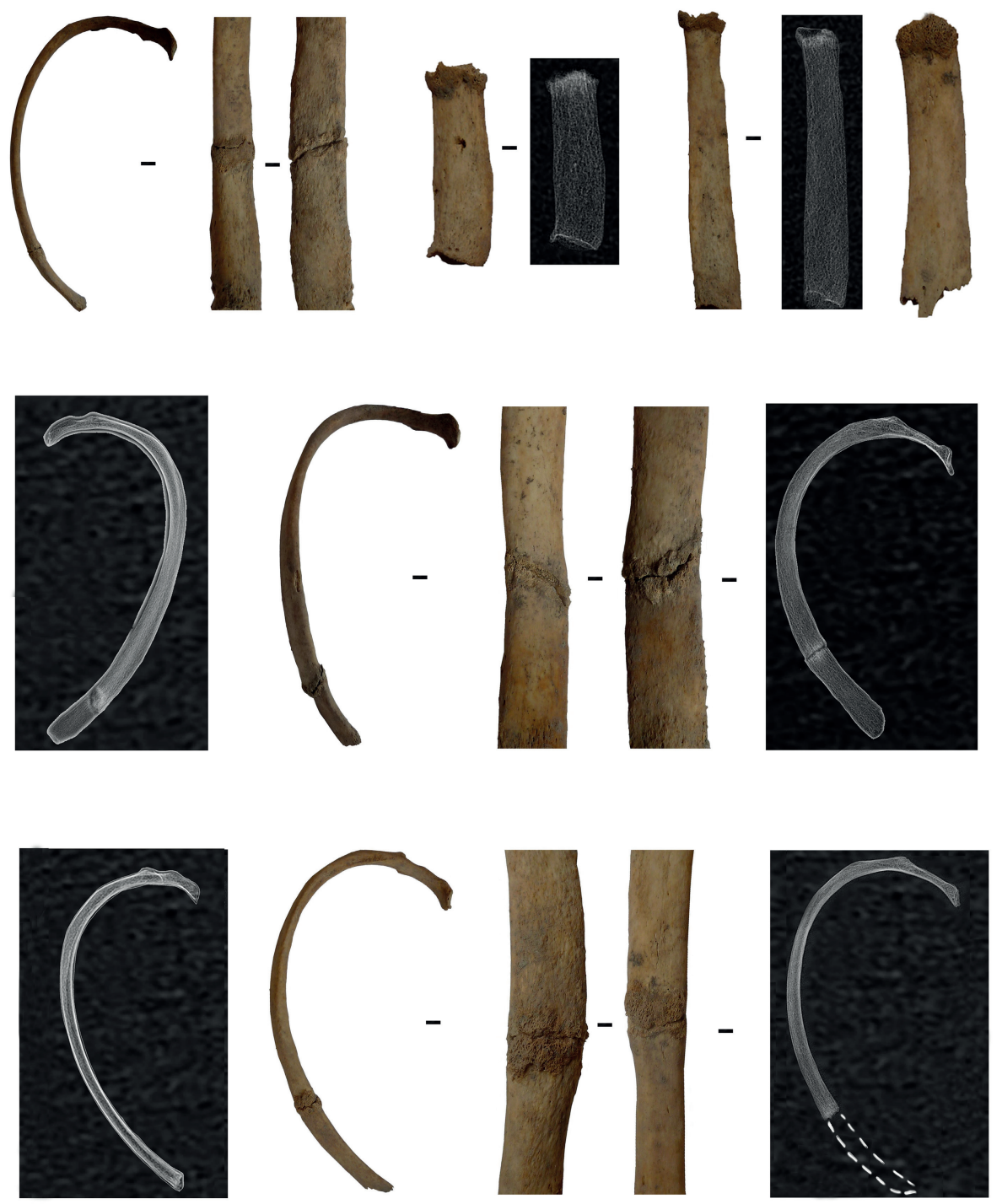

Figure 3. Multiple rib fractures

Ilium of pelvis. The acetabulum also demonstrated a fracture (Figure 2-7). The bone in the acetabulum had become thickened; this may result from attempts at mechanical strengthening following the injury or abnormal positioning. 
Femur. The femoral head had split into five parts, two large fragments and three small ones (Figure 2-12). Bone degeneration of the femoral head over time causes its collapse. Subchondral cysts and porosity were present, and shortening and expansion of the femoral cervix was observable. The femoral fracture co-existed with the pelvic pseudofractures reported above. An X-ray was performed, which showed flattening and increased radiological density of the femoral head and confirmed its mushroom shape (Figure 2-12). There was considerable reduction in the mediolateral diameter of the head. Femora also demonstrated raised, linear ridges of bone formation along the inferior margin of the left femoral cervix, indicating a linear fracture callus formed above an underlying pseudofracture (Figure 2-6). Similar fractures frequently occur as a result of lower-energy falls from standing height with a rearwards or side impact to the hip [32]. Intracapsular hip breaks are related with the femoral neck, and extra-capsular fractures happen in the trochanteric region [59]. Both may result in external rotation of the distal broken portion and shortening of the leg. Long bone fractures in osteomalacia are likely to be caused by an accidental injury affecting the pathologically loosened bone [13].

Thus, the Late Middle Ages specimen can be regarded as the first record of osteomalacia identified in paleoanthropological materials of Armenia. The findings from the study suggest that the individual who lived in the Late Medieval period can have gone through plural episodes of vitamin D deficiency. The individual from St Hripsime Church was diagnosed as having osteomalacia primarily based on the presence of multiple, macroscopically apparent pseudofractures. Overall X-ray analysis reconfirmed the macroscopical diagnosis by pointing out decreased bone density, a coarsened trabecular pattern and typical radiolucent Looser's zones ("pseudofractures"). Probably, osteomalacia strengthened skeletal fragility and muscle weakness [27], which, along with co-occurring osteoporosis in this individual, is likely to have contributed to the growth of the fractures. Pseudofractures also can occur in a variety of circumstances, including osteogenesis imperfecta, osteopetrosis, Paget's disease and congenital syphilis $[39,14]$. However, the design of skeletal occurrence and trend towards bilateral locations affected, particularly in the scapulae and ribs may be correlated with defective mineralisation pointing to vitamin D deficiency [14, 58, 39].

Among researchers, it is broadly assumed that vitamin D deficiency only occurred after humans had left Africa [30]. The earliest evidence of vitamin $\mathrm{D}$ deficiency comes from Tabun and Skhul, Late Pleistocene sites from Mount Carmel, Israel [11]. The prevalence of vitamin D deficiency (osteomalacia) in 
adult ancient Egyptian population from Baharia oasis was 7.4\%, all of whom were adult males. The cases that were detected in the Greco-Roman period of Egypt may be due to mechanical stress during wine and textile production [20]. Ives and Brickley [28] analysed 1081 skeletons from multiple urban contexts in post-mediaeval England (c. 1700-1855). Twelve adults with a proof of osteomalacia were identified. When seven cases preliminarily identified by Brickley et al. [14] are added, the individual abundance rate increases to 19 of 1323 individuals (1.43\%). Increased abundance of osteomalacia evident in the post-Medieval period is ascribable to poor diet and industrial pollution in urban areas $[41,14]$. Research is also continuing to document the occurrence of this condition across the social classes. The study of Ives and Brickley [28] has also enlarged the wide range of macroscopic lesions of adult osteomalacia, maintained by comparisons with clinical cases and microscopic identification of mineralization defects. Vitamin D deficiency as a result of insufficient exposure to sunlight (in particular, in rural individuals who lived in tiny underground houses) and nutritional deficiency could be described as the basic causes leading to osteomalacia in Armenia. A major characteristic of diets in rural Armenia is the high concentration of unrefined cereals [34]. These cereals have a high phytate content, which, in turn, deteriorates calcium absorption [15]. Severe cases of calcium deficiency may additionally result in secondary hyperparathyroidism, which in turn will influence bone structure and health [15]. Similarly, Özgür et al. [48] have suggested that high levels of strontium can inhibit the parathyroid glands and contribute to a reduction in the production of active vitamin D metabolites by the kidneys. In persons, osteomalacia caused by nutritional origin can be rather common [3,21, 52]. Certain dietary preferences can also drive to a deficiency in vitamin $\mathrm{D}$ and calcium. Children and adults consuming stringent vegetarian diets have been shown to be prone to developing vitamin D deficiency $[19,44,47,15]$. Such diets are bereft of any animal products and, without supplementation, radically limit the amount of vitamin D and calcium being consumed [19, 44, 47, 50]. Another factor that could promote osteomalacia in older individuals is a decrease in intestinal absorption of vitamin $\mathrm{D}$ with age [52]. In addition to vitamin D deficiency, general malnutrition (particularly a deficiency of protein and fat), low intake or excessive loss of calcium and phosphorus can promote the development of osteomalacia. Knowing the reasons for vitamin D deficiency will ensure a greater understanding of the lived experience of individuals with osteomalacia in the ancient past. The new manifestation of osteomalacia reported here can help identify more examples in future research. Such research will also help better understand the range of possible causes and factors that operated in the past. 


\section{CONCLUSIONS}

We presented an instance of an incomplete skeleton which provided valuable information on pathological changes connected with osteomalacia. This study aimed to grasp the expression of vitamin D deficiency in the skeleton of an adult via detailed analysis of human bones from St Hripsime Church. The subject under study appeared to be a very interesting instance of an individual whose skeleton showed pathological variations connected with the subject's vitamin D deficiency

\section{ACKNOWLEDGEMENTS}

We thank Pavel Avetisyan, Director of the Institute of Archaeology and Ethnography, National Academy of Sciences, Republic of Armenia, without whose continued support, this research would not have been possible. We would like to thank Harut Davtyan, Director of the Armenian Republican Medical Centre and his staff for the support given during the exploration of the Horom burial. We are also grateful to the staff of the Institute of Archaeology and Ethnography of the National Academy of Sciences of Armenia - Anahit Galstyan for scanning and processing of photos and Ani Sahakyan for the graphic illustration of the skeleton.

\section{REFERENCES}

1. Adams J. (1997). Radiology of rickets and osteomalacia. In: Feldman, D., Glorieux, F., Pike, J. Vitamin D. San Diego: Academic Press, 619-641

2. Alekseev V.P. (1966). Osteometry: Methods of anthropological researches. Moscow: Nauka.

3. Al-Jurayyan N.A., El-Desouki M.E., Al-Herbish A.S., Al-Mazyad A.S., AlQhtani M.M. (2002). Nutritional rickets and osteomalacia in school children and adolescents. Saudi Medical Journal, 23, 182-185.

4. Arabi A., Baddoura R., El-Rassi R., El-Hajj F.G. (2010). Age but not gender modulates the relationship between PTH and vitamin D. Bone, 47, 408-412. https://doi.org/10.1016/j.bone.2010.05.002

5. Autier P., Gandini S. (2007). Vitamin D Supplementation and Total Mortality: A Meta-analysis of Randomized Controlled Trials. Archives of internal medicine, 167, 1730-1737. https://doi.org/10.1001/archinte.167.16.1730 
6. Basha B., Rao D.S., Han Z.H., Parfitt A.M. (2000). Osteomalacia due to vitamin $\mathrm{D}$ depletion in the US. American Journal of Medicine, 108, 296-300.

https://doi.org/10.1016/S0002-9343(99)00460-X

7. Beauthier J.P., Lefevre P., Werquin J.P., Quatrehomme G., Meunier M., Polet C., Orban R. (2008). Les sutures crâniennes ont-elles encore une place dans l'évaluation de l'âge au décès? [Should cranial sutures still be considered in the evaluation of the age at death?]. Journal de Médecine Légale Droit Médical, 51, 203-220.

8. Berry J., Davies M., Mee A. (2002). Vitamin D metabolism, rickets and osteomalacia. Seminars in Musculoskeletal Radiology, 6, 173-181. https://doi.org/10.1055/s-2002-36714

9. Bhan A., Rao A.D., Rao D.S. (2010). Osteomalacia as a result of vitamin D deficiency. Endocrinology and Metabolism Clinics of North America, 39(2), 321-331. https://doi.org/10.1016/j.ecl.2010.02.001

10. Brickley M. (2006). Rib fractures in the archaeological record: a useful source ofsociocultural information? International Journal of Osteoarchaeology, 16, 61-75. https://doi.org/10.1002/oa.809

11. Brickley M.B., D’Ortenzio L., Kahlon B., Schattmann A., Ribot I., Raguin E., Bertrand B. (2017). Ancient Vitamin D Deficiency. Long-Term Trends. Current Anthropology, 58 (3), 420-427. https://doi.org/10.1086/691683

12. Brickley M., Ives R. (2008). The Bioarchaeology of Metabolic Bone Disease. San Diego: Elsevier.

13. Brickley M., Mays S., Ives R. (2005). Skeletal manifestations of vitamin D deficiency osteomalacia in documented historical collections. International Journal of Osteoarchaeology, 15, 389-403. https://doi.org/10.1002/oa.794

14. Brickley M., Mays S., Ives R. (2007). An investigation of skeletal indicators of vitamin $\mathrm{D}$ deficiency in adults: Effective markers for interpreting past living conditions and pollution levels in eighteenth and nineteenth century Birmingham, England. American Journal of Physical Anthropology, 132, 67-79. https://doi.org/10.1002/ajpa.20491

15. Brickley M., Moffat T., Watamaniuk L. (2014). Biocultural perspectives of vitamin D deficiency in the past. Journal of Anthropological Archaeology, 36, 48-59. https://doi.org/10.1016/j.jaa.2014.08.002

16. Brothwell D.R. (1981). Digging up bones: The excavation, treatment and study of human skeletal remains. Ithaca: Cornell University Press.

17. Buikstra J.E., Ubelaker E. (Eds.), 1994. Standards for data collection from human skeletal remains. Proceedings of a seminar at the Field Museum of Natural History. Fayetteville, AR. Arkansas Archaeological Survey, Research Series No. 44.

18. Correia P.H.S., Jorgetti V., Leite M.O.R., Arioli E.L., Batalha J.R., Borelli A. (2000). Papel da histomorfometria óssea no diagnóstico diferencial da 
Osteomalácia. Arquivos Brasileiros de Endocrinologia \& Metabologia, 44, 148-152. https://doi.org/10.1590/S0004-27302000000200008

19. Curtis J.A., Kooh S.W., Fraser D., Greenberg M.L. (1983). Nutritional rickets in vegetarian children. Canadian Medical Association journal, 128, 150-152.

20. El-Banna R.A.E.S., El-Din A.M.S., Eid F.A., Ali W.Y.M. (2014). The Prevalence of Vitamin D Deficiency in Ancient Egyptian Population from Baharia Oasis, the Greco Roman Period. Egyptian Journal of Hospital Medicine, 55, 251-256. https://doi.org/10.12816/0004511

21. Eriksen E.F., Glerup H. (2002). Vitamin D deficiency and aging: Implications for general health and osteoporosis. Biogerontology, 3, 73-77. https://doi.org/10.1023/A:1015263514765

22. Francis R., Selby P. (1997). Osteomalacia. In Reid I., Metabolic Bone Disease in Clinical Endocrinology and Metabolism, vol. 11. London: W.B. Saunders, 145-163. https://doi.org/10.1016/S0950-351X(97)80569-1

23. Gharaibeh M.A., Stoecker B.J. (2009). Assessment of serum 25(OH)D concentration in women of childbearing age and their preschool children in Northern Jordan during summer. European Journal of Clinical Nutrition, 63, 1320-1326. https://doi.org/10.1038/ejcn.2009.99

24. Ginde A.A., Liu M.C., Camargo C.A.Jr. (2009). Demographic differences and trends of vitamin D insufficiency in the US population, 1988-2004. Archives of internal medicine, 169, 626-632.

https://doi.org/10.1001/archinternmed.2008.604

25. Hagenau T., Vest R., Gissel T.N., Poulsen C.S., Erlandsen M., Mosekilde L., Vestergaard P. (2009). Global vitamin D levels in relation to age, gender, skin pigmentation and latitude: an ecologic meta-regression analysis. Osteoporosis International, 20, 133-140. https://doi.org/10.1007/s00198-008-0626-y

26. Holick M.F. (2006). High prevalence of vitamin D inadequacy and implications for health. Mayo Clinic Proceedings, 81(3), 353-373.

https://doi.org/10.4065/81.3.353

27. Holvik K., Ahmed L., Forsmo S., Gjesdal C., Grimnes G., Samuelsen S., Schei B., Blomhoff R., Tell G., Meyer H. (2013). Low serum levels of 25-hydroxyvitamin D predict hip fracture in the elderly: a NOREPOS study. Journal of Clinical Endocrinology and Metabolism, 98, 3341-3350. https://doi.org/10.1210/jc.2013-1468

28. Ives R., Brickley M. (2014). New findings in the identification of adult vitamin D deficiency osteomalacia: Results from a large-scale study. International Journal of Paleopathology, 7, 45-56. https://doi.org/10.1016/j.ijpp.2014.06.004

29. Jablonski N. (2012). The evolution of human skin colouration and its relevance to health in the modern world. Journal of the Royal College of Surgeons of Edinburgh, 42(1), 58-63. https://doi.org/10.4997/JRCPE.2012.114 
30. Jablonski N., Chaplin G. (2013). Epidermal pigmentation in the human lineage is an adaptation to ultraviolet radiation. Journal of Human Evolution, 65(5), 671-675. https://doi.org/10.1016/j.jhevol.2013.06.004

31. Jacobs E.T., Kohler L.N., Kunihiro A.G., Jurutka P.W. (2016). Vitamin D and colorectal, breast, and prostate cancers: a review of the epidemiological evidence. Journal of Cancer, 7(3), 232-240. https://doi.org/10.7150/jca.13403

32. Kanis J. (1994). Osteoporosis. Oxford: Blackwell Science.

33. Khudaverdyan A.Yu., Khachatryan H.H., Eganyan L.G. (2016). Multiple trauma in a horse rider from the Late Iron Age cemetery at Shirakavan, Armenia. Bioarchaeology of the Near East, 10, 47-67.

34. Khudaverdyan A.Yu., Zhamkochyan A.S. Hakopyan N.G., Babayan F.S., Yengibaryan A.A., Khachatryan A.A., Yeganyan L.G. (2018). Anthropological characteristics of the Armenian Highlands population and ethnogenetic situation in South Eastern Europe in the Middle Age. Bulletin of Archeology, Anthropology and Ethnography, 1 (40), 60-88 (In Russian).

https://doi.org/10.20874/2071-0437-2018-40-1-060-088

35. Le May M., Blunt J.W. (1949). A factor determining the location of pseudofractures in osteomalacia. Journal of Clinical Investigation, 28, 520-525. https://doi.org/10.1172/JCI102099

36. Looser E. (1920). Über Spatrachitis und Osteomalacia. Klinische, röntgenologische und pathologisch-anatomische Untersuchungen. Deutsche Zeitschrift für Chirurgie, 152, 210. https://doi.org/10.1007/BF02798519

37. Maat G.J.R. (2001). Diet on age at death determinations based on molar attrition. A review related to the Low Countries. Journal of Forensic OdontoStomatology, 19(1), 18-21.

38. Macdonald H.M., Mavroeidi A., Fraser W.D., Darling A.L., Black A.J., Aucott L., O’Neill F., Hart K., Berry J.L., Lanham-New S.A., Reid D.M. (2011). Sunlight and dietary contributions to the seasonal vitamin D status of cohorts of healthy postmenopausal women living at northerly latitudes: a major cause for concern? Osteoporosis International, 22, 2461-2472. https://doi.org/10.1007/s00198-010-1467-z

39. Mankin H. (1974). Rickets, osteomalacia and renal osteodystrophy. Part I. Journal of Bone Joint Surgery, 56A, 101-128. https://doi.org/10.2106/00004623-197456010-00012

40. Matos V. (2009). Broken ribs: paleopathological analysis of costal fractures in the human identified skeletal collection from the Museu Bocage, Lisbon, Portugal (late 19th to middle 20th centuries). American Journal of Physical Anthropology, 140, 25-38. https://doi.org/10.1002/ajpa.21032

41. Mays S., Brickley M., Ives R. (2006). Skeletal manifestations of rickets in infants and young children in a historic population from England. American Journal of Physical Anthropology, 129, 362-374. https://doi.org/10.1002/ajpa.20292 
42. Meindl R.S., Lovejoy C.O., Mensforth R.P., Carlos L.D. (1985). Accuracy and direction of error in the sexing of the skeleton: Implications for paleodemography. American Journal of Physical Anthropology, 68, 79-85. https://doi.org/10.1002/ajpa.1330680108

43. Mensforth R.P. (2002). Vitamin D deficiency mortality: Impaired immune response in infants and elevated cancer risk in adults. American Journal of Physical Anthropology, 34 (Supplement), 112.

44. Messina V., Mangels A.R. (2001). Considerations in planning vegan diets: children. Journal of the American Dietetic Association, 101(6), 661-669. https://doi.org/10.1016/S0002-8223(01)00167-5

45. Mithal A., Wahl D.A., Bonjour J.P., Burckhardt P., Dawson-Hughes B., Eisman J.A., El- Hajj F.G., Josse R.G., Lips P., Morales-Torres J. (2009). Global vitamin $\mathrm{D}$ status and determinants of hypovitaminosis D. Osteoporosis International, 20, 1807-1820. https://doi.org/10.1007/s00198-009-0954-6

46. Müller R. (2007). Skeletal evidence of vitamin D deficiency in Europe. EAA Summer School eBook, 1, 103-110.

47. Murphy S.P., Allen L.H. (2003). Nutritional Importance of Animal Source Foods. The Journal of Nutrition, 133 (11), 3932S-3935S. https://doi.org/10.1093/jn/133.11.3932S

48. Özgür S, Sümer H, Koçoğlu G. (1996). Rickets and soil strontium. Archives of Disease in Childhood, 75, 524-526. https://doi.org/10.1136/adc.75.6.524

49. Parfitt A.M. (1986). Bone fragility in osteomalacia: Mechanisms and consequences. In: Uhthoff H.K., Current concepts of bone fragility. Berlin: Springer Verlag, 265-270. https://doi.org/10.1007/978-3-642-70709-4_23

50. Pettifor J.M. (2004). Nutritional rickets: deficiency of vitamin D, calcium, or both? American Journal of Clinical Nutrition, 80, 1725S-1729S. https://doi.org/10.1093/ajcn/80.6.1725S

51. Pitt M. (1988). Rickets and osteomalacia. In: Resnick D., Niwayama G., Diagnosis of Bone and Joint Disorders, vol. 8, 2nd ed. Philadelphia: W.B. Saunders, 2086-2119.

52. Reginato A., Coquia J.A. (2003). Musculoskeletal manifestations of osteomalacia and rickets. Best Practice and Research in Clinical Rheumatology, 17, 1063-1080. https://doi.org/10.1016/j.berh.2003.09.004

53. Roberts C., Manchester K. (2005). The Archaeology of Disease. 3rd Edition. New York: Cornell University Press, Ithaca.

54. Robins A.H. (2009). The evolution of light skin color: role of vitamin D disputed. American Journal of Physical Anthropology, 139(4), 447-450. https://doi.org/10.1002/ajpa.21077

55. Rossberg W., Saternus R., Wagenpfeil S., Kleber M., März W., Reichrath S., Vogt T., Reichrath J. (2016). Human pigmentation, cutaneous vitamin D synthesis and evolution: variants of genes (SNPs) involved in skin pigmentation 
are associated with 25(OH)D serum concentration. Anticancer Research, 36(3), 1429-1437.

56. Saraiva G.L., Cendoroglo M.S., Ramos L.R., Araújo L.M., Vieira J.G., Kunii I., Hayashi L.F., Corréa M.P., Lazaretti-Castro M. (2005). Influence of ultraviolet radiation on the production of 25 hydroxyvitamin $\mathrm{D}$ in the elderly population in the city of São Paulo (23o 34'S), Brazil. Osteoporosis International, 16, 1649-1654. https://doi.org/10.1007/s00198-005-1895-3

57. Schmitt A. (2005). Une nouvelle méthode pour estimer l'age au décès des adultes à partir de la surface sacro-pelvienne iliaque. Bulletins et Mémoires de la Société d'Anthropologie de Paris, 17 (1-2), 89-101.

58. Steinbach H. L., Noetzli M. (1964). Roentgen appearance of the skeleton in osteomalacia and rickets. American Journal of Roentgenology, 91, 955.

59. Sevitt S. (1981). Bone Repair and Fracture Healing in Man. Churchill Livingstone, Edinburgh.

60. Smith B.H. (1984). Patterns of molar wear in hunter-gatherers and agriculturalists. American Journal of Physical Anthropology, 63, 39-56. https://doi.org/10.1002/ajpa.1330630107

61. Steinbach H., Kolb F., Gilfillan R. (1954). A mechanism of the production of pseudofractures in osteomalacia (Milkman's syndrome). Radiology, 62, 388395. https://doi.org/10.1148/62.3.388

62. van Schoor N.M., Lips P. (2011). Worldwide vitamin D status. Best Practice \& Research: Clinical Endocrinology \& Metabolism, 25, 671-680. https://doi.org/10.1016/j.beem.2011.06.007

63. Wei R., Christakos S. (2015). Mechanisms underlying the regulation of innate and adaptive immunity by vitamin D. Nutrients, 7(10), 8251-8260.

https://doi.org/10.3390/nu7105392

\section{Address for correspondence:}

Dr. Anahit Khudaverdyan

Institute of Archaeology and Ethnography

National Academy of Sciences

Charents St.15, Yerevan, 0025

Republic of Armenia

E-mail: ankhudaverdyan@gmail.com 